\title{
C-KIT Somatic Point Mutation
}

National Cancer Institute

\section{Source}

National Cancer Institute. C-KIT Somatic Point Mutation. NCI Thesaurus. Code C38407.

A point mutation of the KIT gene that originated in non-germline cells. 